Finance and Economics Discussion Series Divisions of Research \& Statistics and Monetary Affairs Federal Reserve Board, Washington, D.C.

\title{
The Choice at the Checkout: Quantifying Demand Across Payment Instruments
}

\section{Ron Borzekowski and Elizabeth K. Kiser}

2006-17

NOTE: Staff working papers in the Finance and Economics Discussion Series (FEDS) are preliminary materials circulated to stimulate discussion and critical comment. The analysis and conclusions set forth are those of the authors and do not indicate concurrence by other members of the research staff or the Board of Governors. References in publications to the Finance and Economics Discussion Series (other than acknowledgement) should be cleared with the author(s) to protect the tentative character of these papers. 


\title{
The Choice at the Checkout: Quantifying Demand Across Payment Instruments
}

\author{
Ron Borzekowski* \\ Elizabeth K. Kiser ${ }^{\dagger}$
}

April 2006

\begin{abstract}
Dramatic changes have occurred in the U.S. payment system over the past two decades, most notably an explosion in electronic card-based payments. Not surprisingly, this shift has been accompanied by a series of policy debates, all of which hinge critically on understanding consumer behavior at the point of sale. Using a new nationally representative survey, we transform consumers' responses to open-ended questions on reasons for using debit cards to estimate a characteristics-based discrete-choice demand model that includes debit cards, cash, checks, and credit cards. Market shares computed using this model line up well with aggregate shares from other sources. The estimates are used to conduct several counterfactual experiments that predict consumer responses to alternative payment choices. We find that consumers respond strongly to elapsed time at the checkout counter and to whether the payment instrument draws from debt or liquidity. In addition, substitution patterns vary substantially with demographics. New "contactless" payment methods designed to replace debit cards are predicted to draw market share from cash, checks, and credit, in that order. Finally, although we find an effect of cohort on payment technology adoption, this effect is unlikely to diminish substantially over a 10-year horizon.
\end{abstract}

\footnotetext{
${ }^{*}$ Federal Reserve Board, 20th and C St., NW, Washington, DC 20551, ron.borzekowski@frb.gov

${ }^{\dagger}$ Federal Reserve Board, 20th and C St., NW, Washington, DC 20551, elizabeth.k.kiser@frb.gov. The views expressed herein are those of the authors and do not necessarily reflect those of the Board of Governors or the staff of the Federal Reserve System. The authors thank Elizabeth Klee for providing estimates on the checkout time for payment options, and Shaista Ahmed and Elise Tosun for outstanding research assistance.
} 


\section{Introduction}

Technological advances and recent policy initiatives have led to substantial changes in the U.S. payment system, most notably an increasing shift from paper to plastic forms of payment 1 Since the mid-1990's, the volume of checks has decreased dramatically, and is currently falling by about three to five percent per year, while the use of electronic payments has greatly expanded. Annual debit card transactions in the U.S. have been growing at over twenty percent per year, and now exceed the number of credit card transactions. As payments have shifted from paper to plastic, the major payment card associations have been the focus of both government and private antitrust actions. These include the challenge by the U.S. Department of Justice of governance practices at Visa and MasterCard, and the civil suit led by Wal-Mart against the card associations' rules on credit and debit card acceptance $\mathrm{L}^{2}$ Currently, the structure and level of interchange fees - the interbank payments made for each credit or debit card transaction - is a hotly debated policy area in both the U.S. and abroad 3

Central to these policy issues is the consumer's choice of payment instrument. While merchants can choose whether to accept a given form of payment, ultimate sovereignty rests with the consumer's choice of which instrument to pull from his or her wallet. The prior research on this topic has highlighted two key aspects to these decisions: consumer demographics and the attributes of payment methods. Carow and Staten (1999) investigate payment choice at gasoline stations and find that age and education are key factors related to debit card adoption. In more recent work,

\footnotetext{
${ }^{1}$ In 2001, Congress passed The Check Clearing for the 21st Century Act (Check 21), which established the legal validity of a substitute electronic version of a paper check (check conversion). The 1996 welfare reform act mandated electronic Benefit Transfer (EBT) programs be introduced by state and federal government agencies. The Electronic Fund Transfers Act (EFTA) has since been amended to refine the consumer protection laws surrounding electronic payments.

${ }^{2}$ The 2003 decision in U.S. vs. Visa/MasterCard required the card associations to allow bank issuers to issue multiple brands of credit and debit cards. The governance arrangements of the card associations, in which the largest card issuers occupied seats on both networks' boards, were allowed to stand. The Wal-Mart case resulted in a settlement that included an agreement that the networks rescind the "honor all cards" requirement by January 1 , 2004; this change allowed merchants the option of accepting credit cards without accepting like-branded debit cards.

${ }^{3}$ Myriad civil suits have been filed within the past year by retail merchants and merchant trade associations against Visa, MasterCard and multiple card-issuing banks. The complaints reference the level of interchange fees as well as the networks' operating rules that affect merchant behavior when accepting credit or debit card payments. In 2003, the Reserve Bank of Australia (RBA) mandated substantial reductions in some interchanges fees, along with other changes; the EU's Competition Commission continues to scrutinize interchange fees; in the UK, the Office of Fair Trading (OFT) has established in separate decisions in 2005 that Visa and MasterCard engaged in anticompetitive practices and is pursuing further action against them.
} 
Zinman (2005) and Borzekowski, Kiser and Ahmed (2006) find similar demographic results for debit card use, as do several studies examining the adoption of other technologies 4 Klee (2005) presents pairwise discrete-choice estimates of payment choice as a function of consumer demographics 5 Payment methods attributes are shown to be important by Hirschman (1982) and more recently by Jonker (2005). Hirschman identified several important product attributes that affect payment choice, including "leverage potential" and "transaction time," two factors included in our model; Jonker focuses on safety, speed, cost, and ease of use.

We build on both of these approaches by incorporating demographic information and payment attributes into a structural model. We transform our survey data to allow estimation of a discretechoice demand model that includes both a rich set of demographic variables and selected product attributes. These are time at checkout, liquidity, and whether the payment type is electronic. In the model, utility from product attributes may vary with consumer demographics. This characteristicsbased approach allows us to model the consumer's decision among bundles of attributes rather than simply among unique discrete alternatives. The structure of the model also allows the calculation of counterfactual experiments that predict consumer responses to changes in the payment choice set.

The estimation uses a new nationally representative sample of over 1,500 consumers from midyear 2004. The results indicate that consumer preferences for the three stated attributes vary significantly across demographic groups. Valuations of time, tastes for electronic payment, and the utility of liquid instruments all vary with age, education and region. Contrary to some earlier findings, income is not a significant regressor once other factors are controlled for. Predicted market shares from this model align very well with other data sources, giving us strong confidence in the approach.

Using our demand estimates, the outcomes of three counterfactual scenarios are predicted: removing options from the consumer choice set, adding a hypothetical option to the choice set, and aging the consumer population. The first examines the merchant's choice whether to accept a

\footnotetext{
${ }^{4}$ See, for example, Kennickell and Kwast (1997), Mantel (2000), Stavins (2001), and Hayashi and Klee (2003).

${ }^{5}$ Jonker (2005) and Loix, Pepermans and Van Hove (2005) provide similar information for the Netherlands and Belgium, respectively.
} 
given instrument. Since merchants are limited in their ability to price discriminate among payment methods, their only free margin currently is whether to accept a given instrument. (This was precisely the flexibility sought - and obtained in 2004 - in the Wal-Mart suit against Visa and MasterCard.) As a result, we predict the outcome of a merchant decision to restrict consumers' choice sets by dropping each of the four instruments. From this experiment we find that substitution patterns are somewhat asymmetric; for example, removing debit would send consumers to cash, checks, and credit, in that order, but removing checks would divert payments equally to debit and cash, then to credit.

The second experiment examines the adoption of new payment instruments. By altering the characteristics of the elements of the choice set, we estimate the impact of one new product innovation: "flash" or contactless debit. This is a technology that allows debit payments by waving the card over a transponder, rather than swiping the card, and is currently being rolled out by certain networks and several large card-issuing banks. The experiment predicts this enhanced debit technology to take a modest share from the three other options.

As a third experiment, we examine what happens as we "age" the population by examining what would happen if each age cohort adopted the preferences over attributes of the cohort behind them. As already discussed, age is an important factor in payment choice, with older individuals less likely to use debit and more likely to use checks. The outcome of this experiment indicates that cohort clearly affects payment choice, and that we do not expect this effect to disappear over a 10-year horizon.

Overall, the results indicate that debit is primarily replacing cash and checks. As newer, faster forms of debit emerge, the trend should continue, although the results from the last experiment indicate that the change may be gradual. The economic impact of these changes on merchants depends critically on merchants' relative costs of handling cash and checks, as well as on interchange rates for debit transactions. If interchange rates continue to rise, merchants could choose not to accept cards and handle the resulting increased cash and check volumes. From a societal perspective, however, debit is cheaper than either cash or paper processed checks; thus, limited 
acceptance of these cards could be welfare decreasing $\left[{ }^{6}\right.$

Finally, the findings shed light on the relatively slower adoption of debit in the U.S. compared to many other developed economies (see, for example, Bolt and Tieman (2005) and Loix et al. (2005)). Because debit serves primarily as a substitute for cash, we would predict debit card adoption rates to be faster in countries with high cash usage, such as those in Europe. In contrast, the U.S. system has historically had much higher use of credit cards and checks. Because debit is a poorer substitute for these methods, we would expect correspondingly slower adoption of debit in the U.S.

\section{A New Consumer Survey}

Our dataset comes from a special survey instrument issued as part of the Michigan Surveys of Consumers, which samples about 500 households per month and is constructed to be representative of U.S. households. Our dataset includes 1,501 distinct households surveyed over the months of March, April, and May 2004. The nationally representative nature of the sample is an improvement over prior studies that detail U.S. debit card use. For example, the sample for the 2005/2006 American Bankers' Association (ABA)/Dove Study of Consumer Payment Preferences (based on a 2004 survey) consists of checking account holders who voluntary responded to a written survey, with a survey response rate of about 7 percent 7 The Michigan Survey sampling frame, in contrast, includes all U.S. households regardless of account holdings and has a considerably higher response rate (around 70 percent).

Table 1 shows checking account holdings and debit card use in our sample. Eighty-eight percent of households reported having a checking account or a similar transaction account at a depository institution; this is consistent with the 2001 Survey of Consumer Finances (SCF), another nationally representative data source ${ }^{8}$ About 52 percent of households $(60$ percent of households with a checking account) have a debit card $9^{9}$ Approximately 45 percent of households (87 percent of

\footnotetext{
${ }^{6}$ See, for example, Humphrey, Willesson, Lindblom and Bergendahl (2003).

${ }^{7}$ Dove Consulting and the American Bankers Association (2005).

${ }^{8}$ Eighty-nine percent of households in the 2001 SCF reported holding a checking account at some type of depository institution; the SCF definition is slightly broader than the Michigan Survey's.

${ }^{9}$ This number may be an undercount if some respondents with debit-enabled ATM cards were unaware of the cards' POS debit functionality.
} 
households with a debit card) reported having used the card to purchase items at stores in the twelve months preceding the survey. The numbers on debit card use in our survey are generally consistent with results obtained in the 2005/2006 ABA/Dove study ${ }^{10}$

\subsection{Consumer Substitution}

An important advantage of our survey is the set of open-ended questions on the reasons for choosing between debit and other payment options. Two questions were asked in this open-ended fashion: Respondents who reported using debit were asked why they use debit cards, and households who reported that they have a card but do not use debit were asked why not.11

For each respondent, we used keywords to construct three dummy variables for alternatives to debit: cash, check and credit. Each dummy takes on a value of 1 if the respondent mentioned that alternative payment method in their response. These variables are not mutually exclusive; more than one payment substitute could be coded. Both the first and second (if present) reported reasons were used to code these indicators.

Descriptive statistics of reported substitutes are shown in table 2 for debit card users and nonusers, conditional on having a debit card. The left column shows the share of debit card users who use debit instead of the respective alternative payment type. Nearly half ( 48.5 percent) of debit card users mention that debit serves as a substitute for cash. About 32 percent of debit card users report using debit instead of checks, and 19 percent say debit serves as a substitute for credit cards. About 21 percent report no specific alternative payment method. These numbers suggest that debit card users view debit cards primarily as a substitute for "paper" payment methods. This question is explored further in Borzekowski et al. (2006).

The right column of table 2 shows the share of debit non-users who report using the respective

\footnotetext{
${ }^{10}$ The ABA/Dove sample reports that 83 percent of consumers have an ATM/debit card (Dove Consulting and the American Bankers Association (2005) p. 50) and that 81 percent of debit card holders use their card (p. 167). The ABA/Dove sample tends toward more affluent consumers, nearly all of whom have checking accounts and who are likely to have greater access to credit.

${ }^{11}$ The exact text of the questions is as follows: Households who use debit were asked, "We are interested in understanding the reasons why people use debit cards to make purchases. Why do you use your debit card to make purchases? Any other reasons?" Those who reported not using debit were asked, "We are interested in understanding why people don't use debit cards to make purchases. Why don't you use your debit card to make purchases? Any other reason?"
} 
payment type instead of debit. Fifty-five percent refer to credit cards as preferable to debit cards; 31 percent refer to checks and 23 percent refer to cash. Twenty-three percent of debit non-users mention no alternative payment method. Thus, the majority of debit card non-users prefer credit cards to debit cards. These asymmetric findings for debit card users and non-users suggest a heterogeneous response to the underlying payment characteristics; we explore this possibility further in the estimation below.

\section{Model and Estimation}

To apply the demand framework, we first transform the responses to the open-ended questions on reasons for debit card use into a form that allows for estimation of a full discrete-choice model. We use the coded responses on payment choice substitutes to create rankings among the four payment options for each respondent. These rankings are then used as the outcome variables in a rank-order logit model (see Beggs, Cardell and Hausman (1981) and Hausman and Ruud (1987)) that incorporates both product and consumer characteristics. We use the coefficient estimates to construct implied choice probabilities across all four payment alternatives. Because the utility interpretation of the rank-order logit model allows us to infer a structural behavioral response on the part of consumers, we use the estimates to perform counterfactual experiments about changes in the consumer choice set.

\subsection{Constructing Rankings}

From the payment substitutes for debit we recorded above, we construct rankings among payment options, making modest additional assumptions on consumer preferences; the ranking algorithm is summarized in table 3. We define frequent debit users as respondents who use a debit card at least once a week; infrequent users are respondents who have used a debit card within the past 12 months but use it less than once a week. For frequent debit users, debit is ranked first, any mentioned substitute methods are ranked (tied for) second, and any remaining unmentioned substitute methods are ranked (tied for) third. For infrequent debit users, mentioned substitutes 
are ranked first, and debit and any unmentioned substitutes are ranked second. For debit nonusers, mentioned substitutes are ranked first, unmentioned substitutes are ranked second, and debit is ranked third. In cases in which the respondent does not mention a substitute, all non-debit options are assumed to be tied and the rankings are adjusted accordingly.

Although the open-ended questions were asked only of debit card holders, it is useful to predict aggregate market shares for a broader set of households. Therefore, in addition to constructing rankings for debit card holders, we also construct rankings for all checking account holders without debit cards. The extension to all checking account holders requires assumptions on how to construct rankings among payment options for estimation, as well as how to model the consumer choice sets for both estimation and market share prediction.

To create rankings for estimation, we assume that checking account holders without a debit card choose not to use debit; that is, that they are not exogenously constrained from using debit. Thus, we assume that checking account holders without a debit card rank cash, credit and checks equally and rank debit second to these. When predicting market shares after estimation, we similarly assume that these consumers only have three payment choices.

By constructing the rankings in this way, we make some implicit assumptions. First, the nature and structure of the survey do not control for the type of retailer at which the payment choice is made. If one assumes that for all respondents, the payment choice for which they report their preferences was their typical supermarket visit, the assumption is innocuous. If, however, some respondents recall a restaurant, others a department store and others a car dealership, then the results could be misleading. A corollary is that we assume all four options - cash, check, debit and credit - were available at whatever point of sale the customer has in mind. In addition, it is well known that payment methods vary with number of items purchased and dollar value of purchase (see Klee (2005) and others). Our model does not incorporate either the number of items or the dollar value of purchase, and therefore implicitly assumes that the amount and items bought equal those of the "typical" point-of-sale transaction. To check the robustness of our rankings, we performed the estimation using selected alternative rankings; the results do not change in any 
substantive way 12

\subsection{Utility Maximization in the Rank-Order Logit}

Given the rankings, the rank-order logit model allows us to estimate consumer preferences over payment choices. Like the multinomial logit, the rank-order logit specifies implied revealed-preference inequalities generated from reported binary comparisons. These inequalities, along with a distributional assumption on unobserved heterogeneity, generate closed-form choice probabilities. Formally, we assume consumer $i$ 's utility from payment method $j$ takes the following form ${ }^{13}$

$$
u_{i j}=V_{i j}+\epsilon_{i j}
$$

where $V_{i j}$ is the consumer's mean utility from using payment option $j$, and $\epsilon_{i j}$ is a random disturbance which is distributed type I GEV. With this specification, the probability that consumer $i$ ranks payment method $j$ over method $k$ is the standard logit formulation:

$$
\operatorname{Pr}\left(u_{i j}>u_{i k}\right)=\frac{\exp V_{i j}}{\exp V_{i j}+\exp V_{i k}}
$$

Let $R_{i}\left(r_{1}, ., ., r_{J}\right)$ be consumer $i$ 's rankings of the available choices, where $r_{h}$ gives the rank of the choice in position $h$. Then the probability of observing the sequence of rankings is:

$$
\operatorname{Pr}\left(R_{i}\right)=\operatorname{Pr}\left[u_{r_{1}}>u_{r_{2}}>\ldots>u_{r_{J}}\right]=\prod_{h=1}^{J-1} \frac{\exp V_{i r_{h}}}{\sum_{m=h}^{J} \exp V_{i r_{m}}},
$$

where $u_{r h}$ is the utility received from the option ranked in position $h$. We specify this utility as

$$
V_{i j}=\beta\left(X_{i} \otimes Z_{j}\right)
$$

where $X_{i}$ is a $1 \times C$ vector of consumer characteristics, $Z_{j}$ is a $1 \times D$ vector of product attributes,

\footnotetext{
${ }^{12}$ The estimation results using the alternative rankings are available from the authors upon request.

${ }^{13}$ This description follows the derivation and subscripting in Beggs et al. (1981). See Allison and Christakis (1994) for a clear and concise exposition of the model.
} 
and $\beta$ is a $(C D) \times 1$ vector of coefficients.

Substituting this into equation 3 and taking logs, the log-likelihood is:

$$
L(\beta)=\sum_{i=1}^{N} \log \operatorname{Pr}\left(R_{i}\right)=\sum_{i=1}^{N} \sum_{h=1}^{J-1}+\beta\left(X_{i} \otimes Z_{h}\right) \sum_{i=1}^{N} \sum_{h=1}^{J-1}\left[\log \sum_{m=h}^{J} \exp \left(\beta\left(X_{i} \otimes Z_{h}\right)\right)\right]
$$

Note that in this model, an individual consumer's relative preference for any two choices is assumed to be independent of all other choices. In other words, a consumer's preference for, e.g., debit over credit is independent of the availability or the relative rankings of the other choices available. This is a variant of the usual independence of irrelevant alternatives (IIA) property of logit models and derives from the assumptions that the $\epsilon$ 's are independent across choices and that they are extreme value distributed. However, incorporating interaction terms between consumer and choice-specific characteristics implies that the IIA property is relaxed at the aggregate level. ${ }^{14}$

The interactions between household and product attributes allow the utility from product attributes to vary across consumers. The product attributes $Z_{j}$ used in estimation are "electronic," "liquid," and "time." Electronic is a dummy variable that takes on a value of 1 if the payment instrument is electronic from the viewpoint of the consumer (i.e., debit and credit). Liquid is a dummy variable that equals 1 if the instrument draws funds from liquidity rather than from a debt instrument (i.e., all options but credit). Time is the estimated minimum time at the checkout counter for a single item purchased at a supermarket ${ }^{15}$ Table 4 shows the attributes for all payment choices.

Because the choice set contains four elements, the model is identified up to only three product attributes. As a result, the results may be picking up the effect of any other attributes that are

\footnotetext{
${ }^{14}$ Specifically, in the case of a scalar $x_{i}$ and $z_{j}$, the ratio of the market shares of products $j$ and $m$ in the traditional multinomial logit without interaction terms is $S_{j} / S_{m}=\exp \left(\beta z_{j}-\beta z_{m}\right)$, so that the decision between choices $j$ and $m$ is independent of the utility from other choices. In contrast, the ratio of market shares when individual- and choice-specific interactions are included shows that the choice between $j$ and $m$ incorporates the utility derived from every other element of the choice set:

$$
\frac{S_{j}}{S_{m}}=\frac{\frac{1}{N} \sum_{i=1}^{N} \frac{\exp \left(\beta x_{i} z_{j}\right)}{\sum_{k=1}^{J} \exp \left(\beta x_{i} z_{k}\right)}}{\frac{1}{N} \sum_{i=1}^{N} \frac{\exp \left(\beta x_{i} z_{m}\right)}{\sum_{k=1}^{J} \exp \left(\beta x_{i} z_{k}\right)}} .
$$

${ }^{15}$ We are grateful to Beth Klee for providing these estimates. See Klee (2005) for a detailed study of consumer response to time at the checkout counter.
} 
highly correlated with the specified set. For example, instead of one of the attributes we included, we could have specified "anonymity" as an attribute that takes on a value of 1 only for cash. However, given the continuous variation in the time variable and the configuration of the "electronic" and "liquid" dummies taken on by each payment method, we are reasonably confident that we are interpreting the coefficients on our chosen attributes accurately.

Note that no price appears in the consumer utility function. Retail payments are unique in that consumers seldom face an explicit price associated with a given payment method. Because of the absence of price in the model, no price elasticities can be computed using the estimates. Instead, the counterfactual experiments (in particular, the diversion ratios computed from dropping payment options) are used to infer substitution patterns.

The results from estimation of the rank-order logit for all checking account holders are presented in table 5. Older households appear to experience disutility from electronic payment methods and from spending out of liquidity. Households in the two youngest age groups appear the most sensitive to time at the checkout counter, as indicated by the positive coefficients on interactions between checkout time and the older age categories (the youngest age category is omitted). Women appear to have a preference for spending from liquidity relative to men, and men have disutility from checkout time relative to women. Single respondents and those with children are time sensitive. Respondents with a bachelors or graduate degree show disutility from spending from liquidity (or better access to credit). Small business owners show a preference for non-electronic methods. Consumers in the South and West prefer electronic payments more strongly than those in other regions, and consumers in the Northeast have the highest relative valuation of time. Overall, the coefficients show heterogeneity in preferences for product characteristics across demographic groups. We now turn to the market shares constructed from the estimates.

\subsection{Predicting Market Shares}

The aggregate market shares constructed using each sample are shown in Table 6. Our aggregate market shares for debit card holders are very close to those generated in the 2005/2005 ABA/Dove survey, shown for reference at the bottom of the table. Our survey shows a slightly lower share for 
credit and a higher share for checks. These differences are reasonable given the selection bias of ABA/Dove toward more affluent consumers, who all have checking accounts and who are likely to have greater access to credit.

Because they are broadly representative of U.S. consumers (and because it is difficult to make out-of-sample predictions for the unbanked), we use the sample of checking account holders for the model predictions and counterfactual experiments presented below. One caveat on all the market share predictions is that they are not weighted by transaction intensity. Because payment usage rates are not constant across the population, actual market shares will reflect not only preferred payment methods but also the frequency of use of each payment method. This frequency will, of course, vary across merchants and types of transactions.

Recall that to create rankings for estimation, we assumed that checking account holders without a debit card are not exogenously constrained from using debit. For predicting market shares, however, we assume that the choice set for non-debit card holders is restricted to cash, credit and checks. This approach guarantees that the decision not to use debit is reflected in the estimates, but prevents non-cardholders from being predicted to use debit.

The within-sample market shares for checking account holders are shown by demographic group in Table 7, with the aggregate shares shown for reference at the bottom. To compute probabilities for each demographic variable, the values of other characteristics are set equal to the sample means within the respective group. For example, the row labeled "female" shows the probabilities that women in the sample, on average, will choose debit, credit, cash or checks. Thus, the choice probabilities reflect not only the coefficients for the respective demographic variable, but also the composition of the demographic group.

Payment market shares vary considerably by region, with the highest debit card shares in the West, the highest cash shares in the Northeast, and the highest check shares in the Midwest. These shares are consistent with aggregate numbers from the 2005/2006 ABA/Dove survey ${ }^{16}$ For debit card holders, our predicted shares for debit and cash are nearly identical; our credit share is lower and our check share is higher. The differences in the credit and check shares are consistent with

\footnotetext{
${ }^{16}$ The ABA/Dove shares are 33 percent debit, 33 percent cash, 19 percent credit, 11 percent check, and 4 percent gift/prepaid card (Dove Consulting and the American Bankers Association (2005) p. 55).
} 
ABA/Dove's more highly educated sample $\sqrt{17}$

The debit card share is generally decreasing with age; the reverse is mostly true for checks. Note that the check shares are highest for respondents aged 45-64 rather than for those 65 and older; this finding is consistent with recent popular-press writeups of Baby Boomers' slow adoption of automated debit for receiving paychecks and other payments 18 The credit card share is highest for respondents age 65 or older, at around 26 percent, likely reflecting the improved access to credit that results from both a longer credit history and a higher income, both of which are positively correlated with age. (Note that from the regression coefficients, these households' "preference" for spending from an illiquid instrument appears to offset their aversion to using electronic methods.)

Shares differ somewhat by gender, with higher debit card and check shares for women, and higher cash and credit card shares for men. This may reflect differences in shopping patterns, driven by household division of labor, between these two groups. Nonwhites show a greater cash share and a lower check share than whites. Marital status is predictive of shares, with considerably higher cash use by singles, and lower credit and higher check use among divorced respondents.

Respondents with less than a high school education are more likely to choose cash, at a share of about 40 percent, while those with a graduate degree are more likely than others to choose credit, at a share of about 31 percent. Check shares appear to decrease with education level. Perhaps surprisingly, relatively little variation occurs in market shares by income group, and none of the relationships is monotonic in income.

\section{Counterfactual Experiments}

The model generates choice probabilities which aggregate to market shares and incorporates both product and consumer characteristics. We use the model estimates to compute the outcomes of several relevant counterfactual experiments. We perform three types of experiments: (1) dropping each option from the consumer choice set, (2) creating a hypothetical new payment option in the

\footnotetext{
${ }^{17}$ See Dove Consulting and the American Bankers Association (2005) p. 35.

${ }^{18}$ See Nordwall (2005). The propensity of households aged 65 or older to use direct deposit is likely influenced by exogenous exposure to this technology: Recipients of Social Security payments and other government benefits are required to receive them using direct deposit. We speculate that Baby Boomers could alter their behavior similarly once they are exogenously exposed to direct deposit.
} 
consumer choice set, and (3) "aging" the population to predict future payment choice.

\subsection{Dropping a Payment Option from the Choice Set}

The legal and policy debates surrounding payment systems hinge upon both merchant acceptance and consumer use of payment methods. Merchants now have the option of dropping any payment choice, but most do not know exactly how consumers might substitute to other payment methods if forced to do so 19 From a policy perspective, the social costs and benefits of merchant refusal to accept a given payment method depend on consumer substitution behavior. We can use our model to directly evaluate consumer substitution of payment methods for an omitted choice, conditional on the decision to make a purchase at a given merchant 20

The counterfactual choice probabilities are computed for an omission of each payment choice, using the parameter estimates and sample data for respondents with a checking account and restricting the choice set to the respective remaining three options. The resulting aggregate market shares for checking account holders are shown in table 8, with the original within-sample market shares shown below for reference. Below each counterfactual share is the diversion ratio: the percentage of the decrease in market share in the omitted option captured by the respective alternate payment method. When debit cards are omitted, debit card market share is absorbed first by cash, then checks, then credit, leaving cash at by far the most popular option at about 45 percent. When cash is omitted, its initial share percent is split fairly evenly across the remaining options, with a slightly higher percent going to checks. For the omission of credit, the initial 19 percent market share goes first to cash, then to checks and debit (in the same order as the initial market shares). Finally, omitting checks results in about half its original share going to cash, followed evenly by debit and credit.

The breakdowns by demographics, shown in table 9, show similar diversion patterns. Note that an omission of debit is predicted to generate remarkably high cash shares among younger respondents, with 69 percent for the 18-24 age category. Dropping checks from the choice set

\footnotetext{
${ }^{19}$ Recall that the settlement of the Wal-Mart-led suit against Visa and MasterCard guaranteed that merchants can refuse to accept debit (or credit) cards.

${ }^{20}$ Our model does not address the issue of lost business due to refusal to accept a payment method.
} 
causes the bulk of respondents in the oldest age category to divert to cash, followed by credit, then debit.

Although all options clearly serve as substitutes to some degree, the substitution patterns are not symmetric. For example, on average, cash is the strongest substitute for debit, but checks are the strongest substitute for cash. These effects could have a substantial impact on merchant or social costs. Thus, should a merchant refuse to accept debit, it would expect a substantial increase in cash use ${ }^{21}$ Borzekowski et al. (2006) find a substantial price response with respect to debit card fees charged by card-issuing banks; the estimates here suggest that these consumers are most likely to turn to cash as a substitute. According to merchant reports, cash is a relatively inexpensive method of payment for merchants to accept; however, from a societal standpoint, cash production and handling is costly for both governments and depository institutions 22 On the other hand, if cash use were discouraged, merchants might expect a surge in check payments ${ }^{23}$ Although the largest retailers have sophisticated check processing and check fraud protection programs in place, smaller merchants do not, and they (along with depository institutions) could face cost increases from greater check use 24

\subsection{Adding a New Payment Option to the Choice Set}

Predicting consumer demand for new payment instruments is highly relevant for both public policy and industry strategy. Large-scale investments by firms or governments are typically necessary to launch a new payment technology, especially due to the network effects inherent in such systems, and estimates of consumer behavior can help predict how consumers might respond to such investments in infrastructure. The inclusion of product characteristics into consumer utility in our model means that, by combining product attributes to form new payment options, we can calculate predictions

\footnotetext{
${ }^{21}$ In 2003, during the dispute with MasterCard over interchange fees, Wal-Mart temporarily stopped accepting MasterCard signature debit. No data on consumer response to this move are publicly available.

${ }^{22}$ See Humphrey et al. (2003).

${ }^{23}$ Although to our knowledge no widespread programs have been implemented by retail merchants to actively discourage cash use, highway toll systems and public transportation systems have implemented programs to encourage electronic payments rather than cash. See, for example, Amromin, Jankowski and Porter's (2005) analysis of the effects of higher toll prices for cash users on the Illinois Tollway.

${ }^{24}$ The cost of check processing is in decline following the enactment of Check 21 in 2001, which established the legal validity of a substitute electronic version of a paper check. This allows any merchant to "truncate" a paper check at the point of sale and present the check electronically for payment by the issuing depository institution.
} 
of consumer response to hypothetical introductions to the choice set.

For our computation, we replace an already available payment option with a "new" option by altering the characteristics of the existing option. 25 The example we choose is a hypothetical "flash" or "contactless" transaction, for which a consumer waves a card or touches a screen to initiate a payment that draws funds from a deposit account ${ }^{26}$ Such a payment option would access liquidity using an electronic format but would be quicker than debit. We compute counterfactual market shares by "replacing" debit with flash; that is, we replace the attributes of debit with those of flash transactions by reducing the time at the checkout to a conservative industry estimate for that of flash while retaining the other two attributes ${ }^{27}$ We assume that flash time is approximately 15 seconds less than cash (about 30 seconds less than debit) 28

This exercise assumes that flash payment cards are issued by banks and accepted at retail merchants in the same proportions as debit cards, and that adoption is costless for consumers. Nonetheless, because our estimate of the time at checkout for flash transactions is conservative, we view this counterfactual experiment as realistic.

The hypothetical choice probabilities that include flash transactions are shown in table 10, with the original within-sample choice probabilities shown for reference. The model predicts that flash transactions would achieve a market share of around 26 percent, about 40 percent greater than the current market share for debit. Flash transactions are predicted to draw consumers first from cash, then checks, followed by credit. Thus, merchants are unlikely to be able to use flash transactions to reduce the credit card share of transactions (with an associated high interchange fee); however, from a societal perspective, flash payments may be a successful tool to increase the share of electronic transactions. In addition to the overall market shares, the table shows predicted probabilities by age, income and gender. Adoption is predicted to be fairly equal across demographic groups, with

\footnotetext{
${ }^{25}$ An alternative approach would be to compute market shares by adding a fifth element to the choice set. However, because of our limited attributes set, we prefer the current approach of viewing flash as a replacement for debit.

${ }^{26}$ Several initiatives have been recently introduced by depository institutions and payment card associations. See, e.g., Dunleavey (2005) and Rueter (2005). Some of these payment methods are similar to the transponder-based store card common at certain gasoline retailers, which requires the customer only to wave the card in front of a receiver at the gas pump, or to transponder-based highway toll collection.

${ }^{27}$ Recall that to estimate the original model, we entered product characteristics as $Z_{j}=$ $\{I\{$ electronic $\}, I\{$ liquid $\}$, time (in seconds) $\}$, with $Z_{\text {debit }}=\{1,1,50.43\}$. To compute new choice probabilities for flash debit, we replace $Z_{\text {debit }}$ with $Z_{\text {flash }}=\{1,1,20\}$.

${ }^{28}$ See Bradford (2005) and Digital Transactions News (2005).
} 
the exception of a stronger cash preference for respondents age 18-24 relative to other respondents. As discussed above, a caveat to these predictions is that the parameter estimates for checkout time may reflect a preference for any other characteristics of the respective payment methods that are correlated with checkout time.

To summarize, our inference from this experiment suggests that the adoption of flash technology is likely to result in small changes in overall market shares. We predict flash transactions will draw consumers mainly from paper-based methods rather than from credit cards.

\subsection{Aging the Population to Predict Future Payment Choice}

Because debit cards themselves have yet to diffuse fully into the economy, it is useful to predict future adoption rates in order to evaluate the future effects of policy or industry changes. Because we estimate age-specific coefficients for each payment attribute, we can isolate this effect on payment instrument choice from the effects of other factors, such as family structure and home ownership, which are also correlated with age.

Note that because we use a cross section rather than a panel, we cannot identify separate effects for age and cohort. We assume that the age coefficient reflects a cohort effect. For example, in the case of debit, for which use is decreasing in age, we assume that older individuals are empirically less likely to adopt debit because its characteristics comprise a new technology, and not because of a differential response to its characteristics that derives purely from chronological age.

We perform the experiment of "aging the population" in the following way. We first reset the values of the cohort-specific coefficients so that each cohort takes on the coefficient of the next youngest cohort, holding the coefficient for the youngest (omitted) cohort and those of all other demographics at their original values. This ages each cohort by about 10 years (less for the youngest age group, and more for the oldest). We then recompute choice probabilities using respondents' original demographic variables and the new coefficient vector. The effect of this computation is to roll the population forward one cohort while holding constant the distribution of other demographic variables. This approach allows individual respondents to "age" with respect to income, educa- 
tion, and family structure, without changing the overall distribution of demographics 29 We then compute aggregate payment market shares along with market shares by demographic group. The difference between the within-sample and counterfactual market shares can therefore be attributed solely to the cohort effect.

The aggregate counterfactual market shares show that aging the population results in slightly higher debit and cash shares and slightly lower credit and check shares. Debit draws proportionally the most from checks. These predictions are consistent with the strong preference of the current younger respondents for quick checkout being applied to older generations' hypothetical payment preferences. The choice probabilities continue to show substantial differences across demographic groups. As expected, the debit card share is predicted to increase the most among the oldest respondents, increasing from a 9- to a 14-percent market share. Overall, this exercise suggests that the cohort-specific preferences that are currently reflected in consumer payment choice will change as the population ages, but are unlikely to alter the aggregate shares dramatically for the 10-year horizon.

\section{Conclusion}

This paper uses a recent nationally representative survey on U.S. payment preferences at the point of sale to investigate consumers' use of debit cards, credit cards, checks and cash. We demonstrate a method for transforming responses to open-ended survey questions into ranked outcome variables that can be used in a characteristics-based discrete-choice demand system. We then estimate our demand system allowing utility from payment method characteristics to vary with demographic characteristics. Using these estimates, we compute aggregate market shares for each payment instrument and perform the counterfactual experiments of dropping payment methods, predicting demand for an emerging payment method, and synthetically aging the population.

We find that our market shares square well with those computed in other surveys. The market shares vary systematically with age, education, and gender, but less so with income, reflecting the

\footnotetext{
${ }^{29}$ Our approach also implies that each cohort takes on the fixed demographics (gender and ethnicity) of the next cohort up. More favorably stated, it shows a change in hypothetical payment choice due to a change in cohort, leaving constant the effects of other demographic shifts in the population.
} 
competing motives for payment choice that vary with income. From our counterfactual experiments we predict that merchant refusal to accept payments - or other initiatives to alter consumer payment choice - will have differential effects by payment type. That is, substitution patterns are not symmetric. Our experiment predicting the market share of a newly developed "contactless" payment method, which could replace debit cards if new initiatives take hold, suggests this method will attract modest market shares and will draw mainly from paper-based methods. Finally, after synthetically aging the population, we predict that debit is unlikely to make major inroads over a 10-year horizon based purely on the aging of a population with cohort-specific preferences.

Several questions remain open as areas for future research. First, why has debit rather than credit taken the bulk of business away from checks and cash (even for higher-income, non-creditrevolving households)? What is the saturation point for debit card use? Is there a base level of cash and check use that will remain even after debit cards and similar payment technologies have diffused fully into the economy? Answers to these questions and others will help us to understand more fully the complex problem of payment choice. 
Table 1: Sample composition

Sample Size

Percent of Sample

$\begin{array}{lcc}\text { Total Interviewed } & 1,501 & 100.0 \\ \text { Checking Account Holders } & 1,316 & 87.67 \\ \text { Debit Card Holders } & 783 & 52.17 \\ \text { Debit Card Users } & 674 & 44.90\end{array}$


Table 2: Debit cards vs. other payment methods: Substitution

\begin{tabular}{lcc} 
Substitute $^{*}$ & $\begin{array}{c}\text { Percent Who Use Debit } \\
\text { Instead Of Substitute } \\
\text { (Users=674): }\end{array}$ & $\begin{array}{c}\text { Percent Who, Instead } \\
\text { of Debit, Use Substitute: } \\
\text { (Non-Users=109): }\end{array}$ \\
\hline Cash & 48.5 & 22.9 \\
Check & 31.9 & 31.2 \\
Credit & 19.4 & 55.1 \\
Indeterminate & 21.4 & 22.9 \\
\hline
\end{tabular}

* Categories are not mutually exclusive. 
Table 3: Ranking Algorithm

\begin{tabular}{lccc} 
Payment Method & $\begin{array}{c}\text { Frequent } \\
\text { Debit User* }\end{array}$ & $\begin{array}{c}\text { Infrequent } \\
\text { Debit User }\end{array}$ & $\begin{array}{c}\text { Debit } \\
\text { Non-User }\end{array}$ \\
\hline \multirow{2}{*}{ Debit } & 1 & 2 & 3 \\
Mentioned Substitute & 2 & 1 & 1 \\
Unmentioned Substitute & 3 & 2 & 2 \\
\hline
\end{tabular}

*Frequent users are defined as those who use a debit card for purchases once a week or more. 
Table 4: Attributes of Payment Methods

\begin{tabular}{lccc} 
Payment Method & Electronic & Liquid & Time $^{*}$ \\
\hline Debit & 1 & 1 & \\
Cash & 0 & 1 & 30.43 \\
Credit & 1 & 0 & 55.75 \\
Check & 0 & 1 & 77.53 \\
\hline
\end{tabular}

*Estimated minimum time in seconds at checkout for a single item purchased at a supermarket, from dataset used in Klee (2005). 
Table 5: Parameter Estimates from Rank-Order Logit Model

\begin{tabular}{|c|c|c|c|}
\hline Demographic Characteristic & Electronic & Liquid & Time \\
\hline Midwest & $\begin{array}{c}-.468^{* * *} \\
(.178)\end{array}$ & $\begin{array}{l}-.276 \\
(.221)\end{array}$ & $\begin{array}{l}.004 \\
(.006)\end{array}$ \\
\hline Northeast & $\begin{array}{c}-.543^{* * *} \\
\quad(.191)\end{array}$ & $\begin{array}{r}-.402^{*} \\
(.231)\end{array}$ & $\begin{array}{c}-.017^{* * *} \\
(.006)\end{array}$ \\
\hline South & $\begin{array}{l}-.193 \\
(.165)\end{array}$ & $\begin{array}{l}-.268 \\
(.205)\end{array}$ & $\begin{array}{l}-.003 \\
(.005)\end{array}$ \\
\hline $25-34$ yrs & $\begin{array}{l}.197 \\
(.270)\end{array}$ & $\begin{array}{l}-.032 \\
(.351)\end{array}$ & $\begin{array}{l}.009 \\
(.010)\end{array}$ \\
\hline $35-44$ yrs & $\begin{array}{l}-.120 \\
(.276)\end{array}$ & $\begin{array}{l}-.251 \\
(.353)\end{array}$ & $\begin{array}{c}.020^{* *} \\
(.010)\end{array}$ \\
\hline $45-54$ yrs & $\begin{array}{l}-.403 \\
(.280)\end{array}$ & $\begin{array}{l}-.402 \\
(.358)\end{array}$ & $\begin{array}{c}.025^{* *} \\
(.010)\end{array}$ \\
\hline $55-64$ yrs & $\begin{array}{c}-.595^{* *} \\
(.297)\end{array}$ & $\begin{array}{c}-.753^{* *} \\
(.375)\end{array}$ & $\begin{array}{c}.028^{* * *} \\
(.010)\end{array}$ \\
\hline 65 or older & $\begin{array}{c}-1.321^{* * *} \\
(.324)\end{array}$ & $\begin{array}{c}-1.845^{* * *} \\
(.396)\end{array}$ & $\begin{array}{c}.023^{* *} \\
(.010)\end{array}$ \\
\hline Female & $\begin{array}{l}.198 \\
(.124)\end{array}$ & $\begin{array}{c}.416^{* * *} \\
(.152)\end{array}$ & $\begin{array}{c}.014^{* * *} \\
(.004)\end{array}$ \\
\hline Non-white & $\begin{array}{l}-.035 \\
(.157)\end{array}$ & $\begin{array}{l}-.074 \\
(.196)\end{array}$ & $\begin{array}{l}-.007 \\
(.005)\end{array}$ \\
\hline Single & $\begin{array}{l}.044 \\
(.179)\end{array}$ & $\begin{array}{l}-.004 \\
(.214)\end{array}$ & $\begin{array}{c}-.016^{* * *} \\
(.006)\end{array}$ \\
\hline Divorced & $\begin{array}{l}.011 \\
(.180)\end{array}$ & $\begin{array}{l}.442^{*} \\
(.230)\end{array}$ & $\begin{array}{c}.012^{* *} \\
(.006)\end{array}$ \\
\hline Some college & $\begin{array}{l}.186 \\
(.163)\end{array}$ & $\begin{array}{l}-.209 \\
(.208)\end{array}$ & $\begin{array}{l}.003 \\
(.005)\end{array}$ \\
\hline Bachelors degree & $\begin{array}{l}-.014 \\
(.181)\end{array}$ & $\begin{array}{c}-.503^{* *} \\
(.227)\end{array}$ & $\begin{array}{l}.0004 \\
(.006)\end{array}$ \\
\hline Graduate degree & $\begin{array}{l}-.052 \\
(.207)\end{array}$ & $\begin{array}{c}-1.155^{* * *} \\
(.250)\end{array}$ & $\begin{array}{l}-.003 \\
(.006)\end{array}$ \\
\hline
\end{tabular}


Table 5: continued

\begin{tabular}{lccc} 
Demographic Characteristic & Electronic & Liquid & Time \\
\hline Has one or more children & .047 & .103 & $-.009^{* *}$ \\
& $(.142)$ & $(.177)$ & $(.005)$ \\
$\$ 35,000-\$ 59,999$ & .079 & .172 & .002 \\
& $(.182)$ & $(.227)$ & $(.006)$ \\
$\& 60,000-\$ 99,999$ & .136 & .229 & .003 \\
& $(.188)$ & $(.233)$ & $(.006)$ \\
$\$ 100,000$ or more & .179 & .138 & .004 \\
& $(.212)$ & $(.257)$ & $(.007)$ \\
Business phone in household & -.322 & -.228 & -.010 \\
& $(.206)$ & $(.239)$ & $(.006)$ \\
Const. & -.052 & $.788^{*}$ & $-.030^{* *}$ \\
& $(.364)$ & $(.459)$ & $(.012)$ \\
\hline Obs. & 1208 & 1208 & 1208 \\
\hline
\end{tabular}

$* * *$ Significant at $1 \%$ level.

**Significant at $5 \%$ level.

* Significant at $10 \%$ level.

Note: All predictions estimated on population of checking account holders $(1,316$ observations). 
Table 6: Predicted Market Shares

\begin{tabular}{|c|c|c|c|c|}
\hline \multirow[b]{2}{*}{ Predicted for (N) } & \multicolumn{4}{|c|}{ Payment Method } \\
\hline & Debit & Cash & Credit & Check \\
\hline Debit Card Holders (783) & 32.5 & 33.5 & 13.2 & 20.9 \\
\hline Checking Account Holders $(1,316)$ & 16.6 & 37.4 & 19.0 & 27.0 \\
\hline All Consumers $(1,501)$ & 14.4 & 45.7 & 16.5 & 23.4 \\
\hline
\end{tabular}

Note: All predictions for debit card holders estimated on population of debit card holders, otherwise estimated on population of checking account holders. 
Table 7: Predicted Market Shares by Demographic Group

\begin{tabular}{|c|c|c|c|c|}
\hline Predicted for $(N)$ & Debit & Cash & Credit & Check \\
\hline \multicolumn{5}{|l|}{ Region } \\
\hline West (251) & 20.9 & 33.1 & 20.0 & 26.0 \\
\hline Midwest (342) & 14.7 & 35.2 & 17.1 & 32.9 \\
\hline Northeast (253) & 13.0 & 47.6 & 18.8 & 20.6 \\
\hline South (470) & 17.7 & 35.9 & 20.0 & 26.5 \\
\hline \multicolumn{5}{|l|}{ Age } \\
\hline $18-24$ yrs (80) & 24.7 & 53.8 & 11.3 & 10.2 \\
\hline $25-34$ yrs (180) & 27.3 & 40.0 & 17.3 & 15.3 \\
\hline $35-44$ yrs (260) & 21.1 & 36.9 & 17.1 & 24.9 \\
\hline 45-54 yrs (292) & 15.6 & 34.8 & 16.8 & 32.8 \\
\hline 55-64 yrs (232) & 12.4 & 32.1 & 20.1 & 35.4 \\
\hline 65 and older (269) & 6.0 & 38.8 & 26.6 & 28.6 \\
\hline \multicolumn{5}{|l|}{ Gender } \\
\hline Male (611) & 14.6 & 41.3 & 21.6 & 22.4 \\
\hline Female (705) & 18.3 & 34.1 & 16.7 & 30.9 \\
\hline \multicolumn{5}{|l|}{ Race } \\
\hline White $(1,103)$ & 16.1 & 36.5 & 19.4 & 28.0 \\
\hline Non-white (213) & 19.4 & 41.9 & 16.9 & 21.8 \\
\hline \multicolumn{5}{|l|}{ Marital Status } \\
\hline Married (775) & 16.6 & 35.6 & 20.1 & 27.7 \\
\hline Single $(340)$ & 16.9 & 46.6 & 19.6 & 16.9 \\
\hline Divorced (199) & 16.3 & 29.3 & 13.6 & 40.8 \\
\hline \multicolumn{5}{|l|}{ Education } \\
\hline Less than high school (420) & 15.0 & 41.4 & 14.4 & 29.3 \\
\hline Some college (382) & 19.7 & 35.3 & 16.7 & 28.3 \\
\hline Bachelors degree (302) & 17.5 & 37.1 & 19.2 & 26.2 \\
\hline Graduate degree (205) & 12.7 & 34.4 & 31.7 & 21.2 \\
\hline \multicolumn{5}{|l|}{ Children } \\
\hline No children (87r) & 14.1 & 35.9 & 20.5 & 29.4 \\
\hline One or more children (438) & 21.3 & 40.4 & 16.1 & 22.2 \\
\hline \multicolumn{5}{|l|}{ Income } \\
\hline Less than $\$ 35,000 \quad$ (325) & 14.5 & 39.5 & 18.3 & 27.7 \\
\hline$\$ 35,000-\$ 59,000 \quad(304)$ & 17.6 & 36.5 & 16.9 & 29.0 \\
\hline$\$ 60,000-\$ 99,999 \quad$ (332) & 18.3 & 36.9 & 18.7 & 26.1 \\
\hline$\$ 100,000$ or more (254) & 15.9 & 36.6 & 22.8 & 24.7 \\
\hline All checking account holders $(1,316)$ & 16.6 & 37.4 & 19.0 & 27.0 \\
\hline
\end{tabular}

Note: All predictions estimated on population of checking account holders. 
Table 8: Dropping Payment Options

\begin{tabular}{lcccc} 
& \multicolumn{4}{c}{ Market Share } \\
Payment Option Dropped & Debit & Cash & Credit & Check \\
\hline \multirow{2}{*}{ Debit } & & 45.3 & 22.5 & 32.2 \\
& & $(47.6)$ & $(21.1)$ & $(31.3)$ \\
Cash & 26.7 & & 31.3 & 42.1 \\
& $(27.0$ & & $(32.9)$ & $(40.4)$ \\
Credit & 20.0 & 46.6 & & 33.3 \\
& $(17.9)$ & $(48.4)$ & & $(33.2)$ \\
Check & 22.5 & 51.1 & 26.4 & \\
& $(21.9)$ & $(50.7)$ & $(27.4)$ & \\
\hline \multirow{2}{*}{ Original shares } & & & & \\
\hline
\end{tabular}

Note: All predictions estimated on population of checking account holders. Numbers in parentheses are diversion ratios, calculated as the percentage of the decrease in the dropped option's market share drawn by each alternative payment option. 
Table 9: Dropping Payment Options by Demographic Group

\begin{tabular}{|c|c|c|c|c|c|c|c|c|}
\hline \multirow[b]{2}{*}{ Payment Option Dropped } & \multicolumn{4}{|c|}{ Counterfactual Market Shares } & \multicolumn{4}{|c|}{ Within-Sample Market Shares } \\
\hline & Debit & Cash & Credit & Check & Debit & Cash & Credit & Check \\
\hline \multicolumn{9}{|l|}{$\underline{\text { Debit }}$} \\
\hline \multicolumn{9}{|l|}{ Age } \\
\hline $18-24$ yrs & & 70.8 & 15.2 & 14.0 & 24.7 & 53.8 & 11.3 & 10.2 \\
\hline $25-34$ yrs & & 54.9 & 23.7 & 21.4 & 27.3 & 40.0 & 17.3 & 15.3 \\
\hline $35-44$ yrs & & 46.6 & 21.5 & 31.9 & 21.1 & 36.9 & 17.1 & 24.9 \\
\hline $45-54$ yrs & & 41.1 & 19.9 & 39.0 & 15.6 & 34.8 & 16.8 & 32.8 \\
\hline $55-64$ yrs & & 36.6 & 22.8 & 40.5 & 12.4 & 32.1 & 20.1 & 35.4 \\
\hline 65 and older & & 41.3 & 28.2 & 30.5 & 6.0 & 38.8 & 26.6 & 28.6 \\
\hline \multicolumn{9}{|l|}{ Education } \\
\hline Less than high school diploma & & 49.0 & 16.7 & 34.3 & 15.0 & 41.4 & 14.4 & 29.3 \\
\hline Some college & & 44.6 & 20.7 & 34.7 & 19.7 & 35.3 & 16.7 & 28.3 \\
\hline Bachelors degree & & 45.3 & 23.2 & 31.5 & 17.5 & 37.1 & 19.2 & 26.2 \\
\hline Graduate degree & & 39.5 & 36.2 & 24.2 & 12.7 & 34.4 & 31.7 & 21.2 \\
\hline \multicolumn{9}{|l|}{ Gender } \\
\hline Male & & 48.8 & 25.1 & 26.1 & 14.6 & 41.3 & 21.6 & 22.4 \\
\hline Female & & 42.3 & 20.3 & 37.4 & 18.3 & 34.1 & 16.7 & 30.9 \\
\hline \multicolumn{9}{|l|}{ Cash } \\
\hline \multicolumn{9}{|l|}{ Age } \\
\hline $18-24$ yrs & 50.3 & & 28.4 & 21.3 & 24.7 & 53.8 & 11.3 & 10.2 \\
\hline $25-34$ yrs & 45.6 & & 29.9 & 24.5 & 27.3 & 40.0 & 17.3 & 15.3 \\
\hline $35-44$ yrs & 36.2 & & 27.3 & 36.5 & 21.1 & 36.9 & 17.1 & 24.9 \\
\hline $45-54$ yrs & 26.1 & & 26.4 & 47.6 & 15.6 & 34.8 & 16.8 & 32.8 \\
\hline $55-64$ yrs & 21.5 & & 29.8 & 48.7 & 12.4 & 32.1 & 20.1 & 35.4 \\
\hline 65 and older & 14.6 & & 41.0 & 44.4 & 6.0 & 38.8 & 26.6 & 28.6 \\
\hline \multicolumn{9}{|l|}{ Education } \\
\hline Less than high school diploma & 28.9 & & 25.2 & 45.8 & 15.0 & 41.4 & 14.4 & 29.3 \\
\hline Some college & 32.8 & & 27.0 & 40.3 & 19.7 & 35.3 & 16.7 & 28.3 \\
\hline Bachelors degree & 31.2 & & 30.3 & 38.5 & 17.5 & 37.1 & 19.2 & 26.2 \\
\hline Graduate degree & 22.0 & & 47.5 & 30.5 & 12.7 & 34.4 & 31.7 & 21.2 \\
\hline \multicolumn{9}{|l|}{ Gender } \\
\hline Male & 28.3 & & 36.2 & 35.5 & 14.6 & 41.3 & 21.6 & 22.4 \\
\hline Female & 30.5 & & 25.6 & 43.9 & 18.3 & 34.1 & 16.7 & 30.9 \\
\hline
\end{tabular}


Table 9: continued

Counterfactual Market Shares Within-Sample Market Shares

\begin{tabular}{|c|c|c|c|c|c|c|c|c|}
\hline Payment Option Dropped & Debit & Cash & Credit & Check & Debit & Cash & Credit & Check \\
\hline \multicolumn{9}{|l|}{ Credit } \\
\hline \multicolumn{9}{|l|}{ Age } \\
\hline $18-24$ yrs & 29.4 & 59.1 & & 11.5 & 24.7 & 53.8 & 11.3 & 10.2 \\
\hline $25-34$ yrs & 33.9 & 48.2 & & 17.8 & 27.3 & 40.0 & 17.3 & 15.3 \\
\hline $35-44$ yrs & 28.1 & 43.8 & & 28.1 & 21.1 & 36.9 & 17.1 & 24.9 \\
\hline $45-54$ yrs & 21.3 & 39.8 & & 39.0 & 15.6 & 34.8 & 16.8 & 32.8 \\
\hline $55-64$ yrs & 18.0 & 41.3 & & 40.7 & 12.4 & 32.1 & 20.1 & 35.4 \\
\hline 65 and older & 12.2 & 50.2 & & 37.7 & 6.0 & 38.8 & 26.6 & 28.6 \\
\hline \multicolumn{9}{|l|}{ Education } \\
\hline Less than high school diploma & 20.0 & 46.5 & & 33.6 & 15.0 & 41.4 & 14.4 & 29.3 \\
\hline Some college & 25.0 & 42.5 & & 32.5 & 19.7 & 35.3 & 16.7 & 28.3 \\
\hline Bachelors degree & 24.4 & 44.5 & & 31.0 & 17.5 & 37.1 & 19.2 & 26.2 \\
\hline Graduate degree & 21.2 & 48.7 & & 30.1 & 12.7 & 34.4 & 31.7 & 21.2 \\
\hline \multicolumn{9}{|l|}{ Gender } \\
\hline Male & 21.3 & 50.9 & & 27.8 & 14.6 & 41.3 & 21.6 & 22.4 \\
\hline Female & 23.9 & 40.3 & & 35.8 & 18.3 & 34.1 & 16.7 & 30.9 \\
\hline \multicolumn{9}{|l|}{$\underline{\text { Check }}$} \\
\hline \multicolumn{9}{|l|}{ Age } \\
\hline $18-24$ yrs & 28.6 & 57.1 & 14.3 & & 24.7 & 53.8 & 11.3 & 10.2 \\
\hline $25-34$ yrs & 33.1 & 46.3 & 20.6 & & 27.3 & 40.0 & 17.3 & 15.3 \\
\hline $35-44$ yrs & 30.9 & 47.1 & 22.0 & & 21.1 & 36.9 & 17.1 & 24.9 \\
\hline $45-54$ yrs & 26.4 & 48.1 & 25.5 & & 15.6 & 34.8 & 16.8 & 32.8 \\
\hline $55-64$ yrs & 22.0 & 49.0 & 29.0 & & 12.4 & 32.1 & 20.1 & 35.4 \\
\hline 65 and older & 12.8 & 51.7 & 35.5 & & 6.0 & 38.8 & 26.6 & 28.6 \\
\hline \multicolumn{9}{|l|}{ Education } \\
\hline Less than high school diploma & 24.2 & 54.9 & 20.9 & & 15.0 & 41.4 & 14.4 & 29.3 \\
\hline Some college & 28.3 & 47.9 & 23.9 & & 19.7 & 35.3 & 16.7 & 28.3 \\
\hline Bachelors degree & 26.6 & 47.9 & 25.5 & & 17.5 & 37.1 & 19.2 & 26.2 \\
\hline Graduate degree & 18.8 & 41.7 & 39.6 & & 12.7 & 34.4 & 31.7 & 21.2 \\
\hline \multicolumn{9}{|l|}{ Gender } \\
\hline Male & 21.5 & 50.7 & 27.8 & & 14.6 & 41.3 & 21.6 & 22.4 \\
\hline Female & 28.3 & 47.5 & 24.2 & & 18.3 & 34.1 & 16.7 & 30.9 \\
\hline All checking account holders & & & & & 16.6 & 37.4 & 19.0 & 27.0 \\
\hline
\end{tabular}

Note: All predictions estimated on population of checking account holders. 
Table 10: Market Shares for New Payment Technology

\begin{tabular}{|c|c|c|c|c|}
\hline \multirow[b]{2}{*}{ Characteristic } & \multicolumn{4}{|c|}{ Market Share } \\
\hline & Flash & Cash & Credit & Check \\
\hline \multicolumn{5}{|l|}{ Age } \\
\hline $18-24$ yrs & 43.0 & 41.0 & 8.4 & 7.5 \\
\hline $25-34$ yrs & 46.3 & 29.6 & 12.9 & 11.2 \\
\hline $35-44$ yrs & 38.2 & 29.0 & 13.4 & 19.4 \\
\hline $45-54$ yrs & 29.9 & 29.0 & 14.1 & 27.1 \\
\hline $55-64$ yrs & 24.9 & 27.6 & 17.3 & 30.2 \\
\hline 65 and older & 13.2 & 35.8 & 24.6 & 26.4 \\
\hline \multicolumn{5}{|l|}{ Education } \\
\hline Less than high school & 28.3 & 34.7 & 12.3 & 24.7 \\
\hline Some college & 35.2 & 28.1 & 13.6 & 23.1 \\
\hline Bachelors degree & 32.4 & 30.2 & 15.8 & 21.6 \\
\hline Graduate degree & 24.8 & 29.6 & 27.4 & 18.3 \\
\hline \multicolumn{5}{|l|}{ Gender } \\
\hline Male & 27.8 & 34.7 & 18.4 & 19.1 \\
\hline Female & 33.3 & 27.5 & 13.7 & 25.4 \\
\hline All checking account holders & 30.8 & $\begin{array}{c}30.8 \\
(-46.5)\end{array}$ & $\begin{array}{c}15.9 \\
(-21.8)\end{array}$ & $\begin{array}{c}22.5 \\
(-31.7)\end{array}$ \\
\hline Original shares & $\begin{array}{c}16.6 \\
\text { (Debit) }\end{array}$ & 37.4 & 19.0 & 27.0 \\
\hline
\end{tabular}

Note: All predictions estimated on population of checking account holders. Flash market shares are computed assuming the payment method has the electronic and liquid attributes of debit and the time attributes of flash, using an industry estimate (20 seconds). Numbers in parentheses are diversion ratios, calculated as the percentage of the increase in the flash market share drawn from each alternative payment option. 
Table 11: Predicted Market Shares for Debit Card Holders: Aging the Population

\begin{tabular}{lcccc} 
& \multicolumn{4}{c}{ Market Share } \\
& Debit & Cash & Credit & Check \\
\hline Age & & & & \\
18-24 yrs & 24.7 & 53.8 & 11.3 & 10.2 \\
$25-34$ yrs & 24.2 & 48.6 & 14.2 & 13.0 \\
$35-44$ yrs & 26.3 & 40.5 & 16.3 & 16.9 \\
45-54 yrs & 19.3 & 35.0 & 17.8 & 27.9 \\
55-64 yrs & 15.2 & 34.6 & 17.3 & 32.9 \\
65 and older & 12.1 & 36.2 & 19.2 & 32.5 \\
& & & & \\
$\quad$ Education & & & & \\
Less than high school diploma & 18.8 & 42.1 & 12.0 & 27.0 \\
Some college & 22.8 & 37.4 & 14.8 & 25.1 \\
Bachelors degree & 20.1 & 39.8 & 17.2 & 22.8 \\
Graduate degree & 15.0 & 37.3 & 28.6 & 19.0 \\
& & & & \\
$\quad$ Gender & & & & \\
Male & 17.5 & 43.2 & 19.1 & 20.2 \\
Female & 21.6 & 36.1 & 14.7 & 27.6 \\
& & & & \\
All checking account holders & 19.7 & 39.4 & 16.7 & 24.2 \\
\hline & & & & \\
Original shares & 16.6 & 37.4 & 19.0 & 27.0 \\
\hline
\end{tabular}

Note: All predictions estimated on population of checking account holders. 


\section{References}

Allison, Paul D. and Nicholas A. Christakis, "Logit Models for Sets of Ranked Items," Sociological Methodology, 1994, 24, 199-228.

Amromin, Gene, Carrie Jankowski, and Richard D. Porter, "Transforming Payment Choices by Doubling Fees on the Illinois Tollway," 2005. Federal Reserve Bank of Chicago working paper.

Beggs, S., S. Cardell, and J. Hausman, "Assessing the Potential Demand for Electric Cars," Journal of Econometrics, September 1981, 17 (1), 1-19.

Bolt, Wilko and Alexander F. Tieman, "Skewed Pricing in Two-Sided Markets: An IO Approach," January 2005. Working paper, De Nederlandsche Bank.

Borzekowski, Ron, Elizabeth K. Kiser, and Shaista Ahmed, "Consumers' Use of Debit Cards: Patterns, Preferences and Price Response," April 2006. FEDS Working Paper no. 2006-16, Federal Reserve Board.

Bradford, Terri, "Contactless: The Next Payment Wave?," Payment System Research Briefing, December 2005. Federal Reserve Bank of Kansas City.

Carow, Kenneth A. and Michael E. Staten, "Debit, Credit, and Cash: Survey Evidence on Gasoline Purchases," Journal of Economics and Business, 1999, 51 (5), 409-422.

Digital Transactions News, "Absence of Fee Break Could Hinder RFID's Penetration of Cash," November 2005.

Dove Consulting and the American Bankers Association, "Study of Consumer Payment Preferences 2004/2005," December 2005.

Dunleavey, M. P., "In the Blink of an Eye, You've Paid," The New York Times, 2005, December 17, C5.

Hausman, Jerry A. and Paul A. Ruud, "Specifying and testing econometric models for rankordered data," Journal of Econometrics, January - February 1987, 34 (1,2), 83-104.

Hayashi, Fumiko and Elizabeth Klee, "Technology Adoption and Consumer Payments: Evidence from Survey Data," Review of Network Economics, June 2003, 2 (2), 175-190.

Hirschman, Elizabeth, "Consumer Payment Systems: The Relationship of Attribute Structure to Preference and Usage," Journal of Business, 1982, 55 (4), 531-545. 
Humphrey, David, Magnus Willesson, Ted Lindblom, and Goran Bergendahl, "What Does it Cost to Make a Payment?," Review of Network Economics, 2003, 2 (2), 159-174.

Jonker, Nicole, "Payment Instruments as Perceived by Consumers - a Public Survey," September 2005. Working paper, De Nederlandsche Bank.

Kennickell, Arthur B. and Myron L. Kwast, "Who Uses Electronic Banking? Results from the 1995 Survey of Consumer Finances," July 1997. Prepared for presentation at the Annual Meetings of the Western Economic Association, Seattle, Washington.

Klee, Elizabeth, "Families' Use of Payment Instruments During a Decade of Change in the U.S. Payment System," November 2005. Working paper, Federal Reserve Board.

Loix, Ellen, Roland Pepermans, and Leo Van Hove, "Who's Afraid of the Cashless Society? Belgian Survey Evidence," October 2005. Working paper, Free University of Brussels.

Mantel, Brian, "Why Do Consumers Pay Bills Electronically? An Empirical Analysis," Economic Perspectives, 2000, (Quarter IV), 32-47.

Nordwall, Eric, "Boomers Avoid Direct Deposit," USA Today, December 27, 2005, p. B1.

Rueter, Thad, "Contactless Payments: Smooth Sailing, So Far," Cards and Payments, December 2005, $18(9), 20-24$.

Stavins, Joanna, "Effect of Consumer Characteristics on the Use of Payment Instruments," New England Economic Review, 2001, (3), 19-31.

Zinman, Jonathan, "Debit or Credit?," 2005. Working paper, Dartmouth University. 